\title{
Changes of Wilkins Ice Shelf over the past 15 years and inferences on its stability
}

\author{
M. Braun ${ }^{1}$, A. Humbert ${ }^{2}$, and A. Moll ${ }^{1}$ \\ ${ }^{1}$ Center for Remote Sensing of Land Surfaces (ZFL), University of Bonn, Germany \\ ${ }^{2}$ Institute for Geophysics, University of Muenster, Germany \\ Received: 15 April 2008 - Published in The Cryosphere Discuss.: 23 May 2008 \\ Revised: 9 March 2009 - Accepted: 9 March 2009 - Published: 18 March 2009
}

\begin{abstract}
The Wilkins Ice Shelf is situated on the Antarctic Peninsula, a region where seven ice shelves disintegrated or retreated between 1995 and 2002. This study combines various remote sensing datasets from Wilkins Ice Shelf, with the aim of detecting its present and recent dynamics as well as recent changes. The survey includes structural mapping, ERS-1/2 SAR interferometry and analysis of ICESat GLAS ice surface elevation data. Ice front retreat rates from 1986 to 2008 showed several distinct break-up events, including one in February 2008, when $40 \%$ of a part of the ice shelf that connected two islands broke off. Surface elevations have been used to study tidal effects, crack formation and to estimate the ice thickness over the floating area. The derived interferometric velocities cover the south-eastern part of the ice shelf as well as major tributaries and reveal maximum inflow speeds of up to $330 \mathrm{ma}^{-1}$. We show that drainage of melt ponds into crevasses were of no relevance for the break-up at Wilkins Ice Shelf. Buoyancy forces caused rift formation before the break-up in February 2008. Additionally, the evolution of failure zones of the order of tenths of kilometres in length in pre-conditioned locations at ice rises is shown. Investigation of the current (February 2009) situation shows that about $3100 \mathrm{~km}^{2}$ at the Northern Wilkins Ice Shelf are endangered, however, there is no visible signature that the remaining $8000 \mathrm{~km}^{2}$ are at risk.
\end{abstract}

\section{Introduction}

Ice shelves, sandwiched between warming atmosphere and ocean, are sensitive elements of the climate system. The retreat (Wordie, Mueller, Larsen B) and disintegration (Jones, Prince Gustav Channel, Larsen Inlet, Larsen A) of

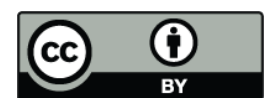

Correspondence to: M. Braun (matthias.braun@uni-bonn.de) various ice shelves on the Antarctic Peninsula showed the potential of ice shelves to become unstable (Doake and Vaughan, 1991a; Vaughan and Doake, 1996; Ward, 1995; Fox and Vaughan, 2005; Skvarca, 1993; Rott et al., 1996 , 1998, 2002; Doake et al., 1998; Skvarca et al., 1999). We introduce here the following terminology in order to be able to distinguish between the varieties of observed changes on ice shelves properly: calving is an ordinary mass loss mechanism of an ice shelf on the time scale of month to years. Retreat is a reduction of size of an ice shelf (while it still remains existent) on the time scale month to years. Disintegration refers to a complete disappearance of an ice shelf with no specific timescale, while a collapse is disintegration on short time scales of days to weeks. Finally, a break-up is a sudden, fast release of fragments of variable size, happing on the time scale of hours to days.

Ice shelves are buttressing glaciers and ice streams - a role which is not yet well understood. Recently, glaciers along the Antarctic Peninsula have shown that they respond to ice shelf disintegration with increased discharge of ice (de Angelis and Skvarca ,2003; Rignot et al., 2004, 2005; Scambos et al., 2004). The retreat, break-up and disintegration of ice shelves have been frequently linked to the observed warming in the last decades and surface melt. Various authors report air temperature increase on the Antarctic Peninsula of up to $2.5 \mathrm{~K}$ since the 1950 's (e.g. King, 1994; Harangozo et al., 1997; Comiso et al., 2000; Meredith and King, 2005; Turner et al., 2005). Surface melt extend and duration was investigated by numerous authors, who mostly report increased extend and duration: Ridley (1993), Torinesi et al. (2003), Morris and Mulvaney (2004), Vaughan (2006) and Tedesco (2008). King and Harangozo (1998) suggest that the observed warming is a result of an increase of the northerly atmospheric circulation component over the Antarctic Peninsula. This is in agreement with findings by Turner et al. (1997) who report a 50\% increase of the winter precipitation events compared to the 1950s. A

Published by Copernicus Publications on behalf of the European Geosciences Union. 
doubling in snow accumulation since the 1850s on the South-Western Antarctic Peninsula was recently observed by Thomas et al. (2008). The $-9^{\circ} \mathrm{C}$ isotherm of mean annual air temperature has been suggested as an approximation of the limit for the viability of ice shelves (Morris and Vaughan, 2003; Vaughan et al., 2001). At present it appears that this isotherm crossing the only two remaining large ice shelves on the Western Antarctic Peninsula: Wilkins and GeorgeVI ice shelves. If this postulation of the limit of viability of ice shelves is valid the Wilkins Ice Shelf (WIS) might be affected as already suggested by Doake and Vaughan (1991b). On the other hand Vaughan and Doake (1996) speculated that WIS might first react with thickening due to increased accumulation.

First evidence of changes exists also for the adjacent ocean on the Western Antarctic Peninsula, which experienced warming of the surface water of up to $1 \mathrm{~K}$ (Meredith and King, 2005). The database is however scarce and the knowledge on the precise role of the ocean in the regional climate change of the Antarctic Peninsula remains unclear (Clarke et al., 2007). Higher ocean temperatures presumably increase basal melt rates of ice shelves, which led Shepherd et al. (2003) to link the observed continuous thinning of Larsen Ice Shelf prior to its disintegration to possible ocean warming. The term "ocean warming" refers to warming of deep water, as well as to the effect of high saline shelf water production by sea ice formation and the heat exchange between atmosphere and ocean, that affects the upper water masses only. Observations by Nicholls et al. (2004) found that Modified Weddell Deep Water flowing across the continental shelf might be responsible for bottom melt on Larsen-C Ice Shelf, while changes in temperature of the deep Weddell Sea are unlikely to have major impact on basal melt rates of Larsen-C Ice Shelf. The oceanographic situations of the Western and Eastern Antarctic Peninsula differ considerably, so that a unique response is unlikely to exist.

We conclude that there are clear signs of extraordinary regional changes. However, the changes are not yet completely assessed and in particular the interactions between different components are known only to a limited extend. Among those is the connection between increased surface temperatures and ice shelf break-up and disintegration.

Increased surface melting has frequently been considered as key factor for ice shelf break-up and collapse. Disintegration and break-up of ice shelves, have led to different theories on mechanisms for ice shelf break-up:

- Ice shelf collapse may have been initiated along glaciological discontinuities, e.g. shear margins, in which melt-ponds drained into (Glasser and Scambos, 2008). Structure-glaciological criteria have already previously been suggested by Doake and Vaughan (1991b) in heterogeneous ice shelf areas. We classify this as primary process or cause. As we show below, other candidates for primary processes are likely to exist as well.

- Surface melt ponds are since long suspicious to drain into surface crevasses and cause them to propagate through the entire ice shelf (Weertman, 1973; Van der Veen, 1998; Scambos et al., 2000, 2003). Glasser and Scambos (2008) infer from the timing of the observed break-up events that surface melt water is the root cause (while we classify it as secondary process or trigger) since most of the break-up events were observed in mid to late austral summer so far.

- Once the crevasses and fractures turned into rifts tertiary processes (or consequences) take place. One of those is the capsize mechanism, that explains the rapid expansion of the rifted ice shelf over the ocean surface by capsizing fragments (MacAyeal et al., 2003).

The aim of this study is to improve the characterization of WIS in regard to its structure, dynamics and fracturing by integrating various remote sensing datasets from 1986 to 2008. The glaciological ice shelf structure is mapped from multi-spectral and SAR satellite imagery with a particular emphasis on structures related to break-up events. The recent flow regime of large parts of the ice shelf is derived from differential SAR interferometry. The computed ice thickness, based on repeated ICESat tracks, completes the surveillance.

\section{Previous knowledge on Wilkins Ice Shelf}

WIS has a size of about $13000 \mathrm{~km}^{2}$ (January 2008) and is confined by Alexander, Latady, Charcot and Rothschild Islands (Fig. 1). Very few in-situ measurements exist for WIS. In the classification scheme for ice shelves (Vaughan, 1998), WIS is associated to Type G, which means that the dominant mass gain mechanism is surface accumulation, and the dominant mass loss mechanism is basal melting. Therefore, changes in ocean circulation and temperature represent contributions to a possible instability of the ice shelf. Furthermore, Type G ice shelves were expected to respond rapidly to changes in surface accumulation (Vaughan, 1998). Although surface accumulation is dominant, there is some contribution from inflow. Lewis Snowfield is the main tributary inflow to the central part of the ice shelf (Vaughan et al., 1993). This coincides with abrupt changes in ice shelf surface elevation at the junction between the two inflowing ice masses in this area (see e.g. Fig. 3 and also flow-unit boundaries in Fig. 5). One of the largest tributary glaciers to WIS is Gilbert Glacier draining the northern part of Alexander Island. Ice from the Colbert Mountain Range drains into Schubert and Haydn inlets. However, the outflow from these inlets into the 


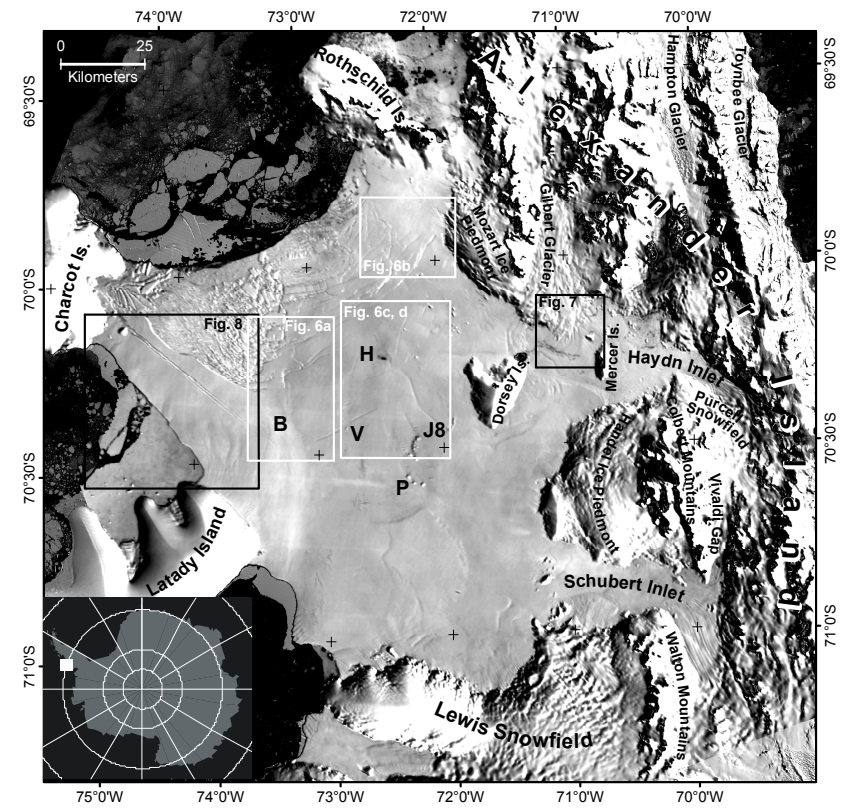

Fig. 1. Map of the study site. WIS is confined by Alexander, Latady, Charcot and Rothschild Islands. The outflow from the two inlets (Haydn and Schubert) into the central ice shelf is interfered by ice rises. Dominant inflow is attributed to Lewis Snowfield, minor inflow from Gilbert Glacier. Various locations mentioned in the text are denoted $(\mathrm{B}=\mathrm{Burgess}$ Ice Rise, $\mathrm{V}=$ Vere Ice Rise, $\mathrm{P}=$ Petrie Ice Rises). Locations of Figs. 6, 7 and 9 are outlined. Background image: MOA 2003/04 (C NSIDC).

central part is partially obstructed by numerous ice rises as visible in Fig. 2. The central part of the ice shelf is thus divided into a thin northern part $(50-150 \mathrm{~m})$ and a thicker south-western part (170-270 m) that extends towards Latady and Charcot Islands (Fig. 3). In contrast, the inlet areas are considerably thicker: as much as $240 \mathrm{~m}$ in Haydn Inlet and $380 \mathrm{~m}$ in Schubert Inlet. A shallow hole, drilled in 1972, penetrated soaked snow and found a water layer at $5.5 \mathrm{~m}$ (Swithinbank, 1988). Radio echo sounding data from the ice shelf (available through BEDMAP meta-database, Lythe, 2000) also indicate sea water (brine) infiltration, since in large parts of the ice shelf no return signal was captured (Vaughan et al., 1993). This can be understood from relatively large accumulation values: Peel (1982) has recorded $0.5 \pm 0.06 \mathrm{~m} \mathrm{a}^{-1}$ water equivalent (w.e.) for the central part of the ice shelf and Arthern et al. (2006)

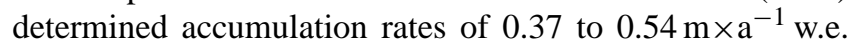
from satellite data. This leads together with a mean annual surface temperature above $-9.0^{\circ} \mathrm{C}$ to a pore closure depth well below $100 \mathrm{~m}$, allowing brine infiltration. Smith (1972) also reports that radio echo soundings (RES) records of ice thickness changed abruptly from $200 \mathrm{~m}$ to $50 \mathrm{~m}$ without a detectable change in surface elevation, which can only be understood by sea-level brine infiltration.
Based on passive microwave imagery Ridley (1993) showed that the WIS experienced a positive trend in melt days of $1.05 \pm 0.95$ days a $^{-1}$ (1977-1991), which corresponds roughly to about 90 days per year (1991). This is the highest amount of all ice shelves on the Antarctic Peninsula. An updated time series (1987-2008) presented by Tedesco (2008) revealed a negative trend of around -0.4 days $\mathrm{a}^{-1}$. Ice shelves like WIS are dominated by surface accumulation and basal melting (although no quantification of this exists so far) happen to have small horizontal velocities, which also holds true for the WIS as will be shown below. A single point measurement from the early 1970's (Vaughan et al., 1993) revealed a surface velocity of $59 \mathrm{~m} \mathrm{a}^{-1}$ in the central part of the ice shelf (see J8 in Fig. 1). In the same study, speeds from satellite feature tracking at few locations uncovered velocities from 30-90 $\mathrm{m} \mathrm{a}^{-1}$.

Vaughan et al. (1993) performed a comprehensive remote sensing analysis including structural mapping, ice dynamics, ice thickness's and GEOSAT surface elevations. GEOSAT ice surface elevations were also investigated by Mantripp et al. (1992) and corrections to these elevations were performed by Cooper and Hinton (1996), mentioning that the most errors were introduced by topographic features and former published slopes might be incorrect up to $18 \%$, leading to overestimation of the width of features, particularly ridges in the ice.

In another remote sensing study, Lucchita and Rosanova (1998) inspected ice front changes on the northern ice front. They report that no significant ice front changes had occurred prior to 1992. Scambos et al. (2000) detected a catastrophic-style break-up event in March 1998 leading to an area loss of about $1100 \mathrm{~km}^{2}$ also on the northern ice front.

\section{Survey}

In order to improve the understanding of the dynamics and recent changes of WIS, elementary baseline datasets such as topography and ice thickness, the location of grounded areas, changes of frontal positions, structures including rifts, shear margins, open water as well as main inflow gates and a velocity field are required.

\subsection{Image database}

Over the last 22 years, a comprehensive collection of satellite images was compiled comprising multi-spectral imagery from Landsat TM and Terra ASTER sensors as well as cloud and illumination independent SAR imagery from the European Remote Sensing Satellites (ERS-1/2) and European Environmental Satellite (ENVISAT) missions, operated by the European Space Agency (ESA). 


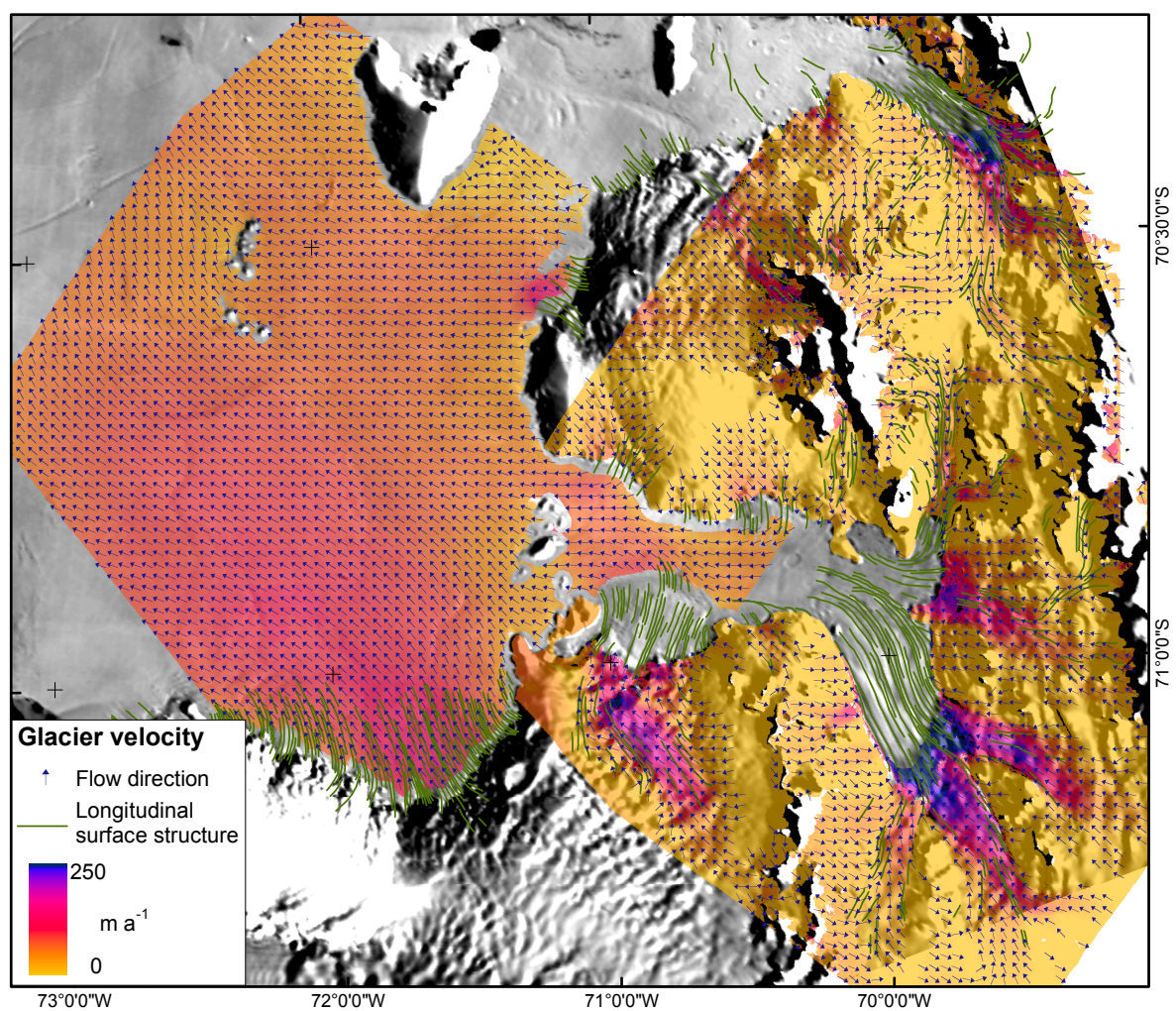

Fig. 2. Interferometric velocities superimposed on a MOA image from 2003/04 (@ NSIDC). Velocities and flow direction of the south-western tributaries of Wilkins Ice Shelf are shown. The data was derived utilizing ascending and descending passes from ERS-1/2 tandem data from October 1995. 2-D velocities of the ice shelf have been computed from repeat overpasses of ERS-1/2 SAR during the ice phase (March 1994) and tandem phase (March 1996). Main inflow origins from Lewis Snowfield; minor contributions are from Handel Ice Piedmont and Schubert Inlet. Flow structures mapped from Landsat imagery (27 January 1990) are displayed in green.

The available Landsat dataset for this study consists of the two scenes per track acquired on 18 February 1986 (path 220, rows 109 and 110) and 27 January 1990 (path 221, rows 109 and 110). These datasets were provided via the Geographic Information System Antarctica (Sievers and Bennat, 1989). Additionally, the Landsat Image Mosaic of Antarctica (http: //lima.usgs.gov) from the late 1990's beginning 2000 was incorporated. Various, nearly cloud-free stripes of the Terra ASTER sensor covering a period between 2001 and 2006 were assembled into a mosaic. For specific areas, complementary ASTER imagery from 2006, January 2008 and 28 February 2008 was georeferenced. The multi-spectral database was completed by concurrent MODIS imagery from 2002 to date from the online archive provided by National Snow and Ice Data Center (http://nsidc.org/data/).

A time series of high-resolution ERS-1/2 and ENVISAT SAR imagery covering the northern ice front was compiled. Since 1991, at least one image per year was processed in order to document changes in ice front position. The time series was completed with ENVISAT data from 2006 to 2008. For the interferometric analysis various datasets from ascending and descending passes of the second ERS ice phase (1994) and the ERS-1/2 tandem phases (1995/96) were combined. The monitoring of the break-up events based on a time series composing of ENVISAT ASAR Wide Swath Mode imagery ( $150 \mathrm{~m}$ pixel size) and ENVISAT ASAR image mode $(25 \mathrm{~m}$ pixel size) was acquired. Furthermore, ALOS PALSAR fine beam imagery ( $7 \mathrm{~m}$ pixel size) from July and November 2007 was processed in order to make use of the deeper penetration depth of this L-band system. During 2008 various high-resolution TerraSAR-X scanSAR and stripmap mode images $(15 \mathrm{~m}$ and $3 \mathrm{~m}$ pixel size, respectively) have been acquired to map fracture development.

\subsection{Interferometric velocities}

For the main tributary glaciers from Alexander Island and Lewis Snowfield a surface velocity field (Fig. 2) was computed by differential SAR interferometry (DInSAR). ERS-1/2 tandem data from $23 / 24$ and 28/29 October 1995 were combined for the analysis. The precision of

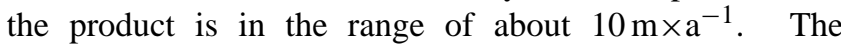
precision was determined in rocky areas where the global solution of the phase unwrapping process should lead to zero velocities. The resulting flow field depicts the main tributaries and flow structure very well. The flow directions computed by DInSAR coincide well with the 


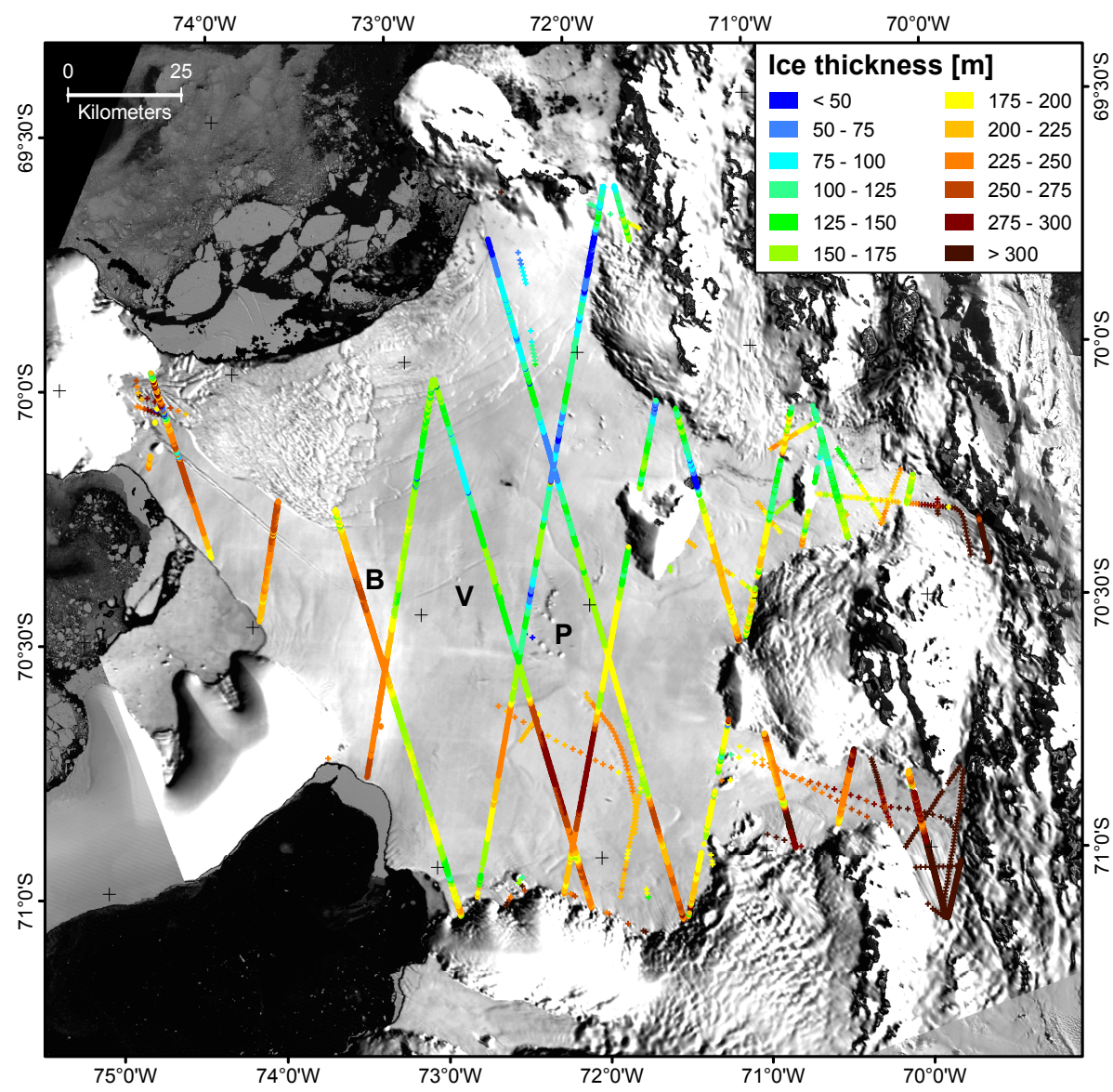

Fig. 3. Ice thickness derived from application of the hydrostatic equilibrium to free board heights from ICESat GLAS surface elevations. Crosses show radio echo sounding data from the British Antarctic Survey from 1966/67, 1969/70, 1971/72 and 1974/75. Background image: MOA 2003/04 (@ NSIDC).

longitudinal surface structures (flow structures) mapped from LANDSAT imagery. Highest velocities are recorded at the southern inflows to Schubert and Haydn Inlet with more than $300 \mathrm{~m} \mathrm{a}^{-1}$. The RES data shows thickness values of more than $500 \mathrm{~m}$ for these areas (Fig. 3).

For WIS a 2-D surface velocity field (Fig. 2) has been computed by SAR interferometry by combining ascending (8/11 March 1994) and descending (3/4 March 1996) viewing directions. Since no concurrent velocity measurements exist, the only available in-situ velocity (J8, $59 \mathrm{~m} \mathrm{a}^{-1}$ ) from 1972 (Vaughan et al., 1993) had to be used for phase-velocity conversion. Although this limits the precision of the absolute magnitude of the velocities for the dataset, the relative velocities and their spatial pattern provide new information. On the ice shelf near Handel Ice Piedmont, manual feature tracking using optical imagery from 1986, 1990 and 2001 revealed no significant changes in velocities, however, this manual feature tracking is limited by the spatial resolution, the low flow speeds and feature deformation over time. Compared to other ice shelves, WIS is an ice shelf with low ice velocities, as can be expected from its mass gain and loss mechanisms. The general pattern shows inflow from Lewis Snowfield with up to $180 \mathrm{~m} \mathrm{a}^{-1}$ and in the central part of the ice shelf velocities in the range of $50-100 \mathrm{~m} \mathrm{a}^{-1}$. This in good agreement with the speeds found by Vaughan et al. (1993), which reports overall speeds of $30-90 \mathrm{~m} \mathrm{a}^{-1}$ that were detected through manual feature tracking. The central part is mainly fed by inflow from Handel Ice Piedmont $\left(\sim 100 \mathrm{~m} \mathrm{a}^{-1}\right)$ and Lewis Snow Field. This coincides with the observed ice thickness gradients on the ice shelf. Only very small velocities are recorded for the outflow from Schubert Inlet confirming the interpretation that the ice rises restrict mass flow towards the ice shelf. Considering the mass gain from the thick and fast tributary glaciers to Schubert Inlet it has to be assumed that main mass loss in the inlet areas occurs by basal melting. Figure 2 also reveals that there is almost no outflow from Haydn Inlet into the central part of the ice shelf. Furthermore, the velocity field depicts very well small-scale variations on the ice shelf as can be seen from the perturbations induced by the small ice rises (e.g. downstream of Petrie Ice Rises, Fig. 3). 


\subsection{Topography}

ICESat (Ice, Cloud, and Land Elevation Satellite) GLAS (Geoscience Laser Altimeter System) ice surface elevation data from the operation periods $2 \mathrm{~A}, 2 \mathrm{~B}, 3 \mathrm{~A}, 3 \mathrm{~B}, 3 \mathrm{D}, 3 \mathrm{E}$, 3F, 3G and 3H (26 September to 18 November 2003, 25 February to 21 March 2004, 6 October to 5 November 2004, 21 February to 23 March 2005, 24 October to 23 November 2005, 24 February to 27 March 2006, 24 May to 26 June 2006, 2 to 21 November 2006, 12 March to 14 April 2007, respectively) from GLA06, release 28, were used to study ice shelf surface heights and to compute the ice thickness. Satellite and geophysical corrections where applied, while the provided tidal corrections were not applied. Therefore, the shown elevations include elevation variations from all kind of sources, including tides, those arising from the mass balance as well as evolution of fractures. Elevations are transformed from the Topex/Poseidon ellipsoid to the EGM96 geoid, so that the given elevations are freeboard heights.

In order to eliminate differences in the track positions at the various operation times of the ICESat GLAS instrument in our analysis along track, we define a box around the ice shelf area and calculate the intersection between the track (assumed to be linear) and the right margin of the box. This gives one "base" point per track per operation period, from which distances are calculated.

Since no tidal measurements were ever performed on the WIS, differences between the ICESat GLAS surface elevations at different operation periods open for the first time the opportunity to determine the range of tidal displacement of the WIS. Histograms of the difference in elevation of all tracks reveal a maximum tidal range of $1.2 \mathrm{~m}$. As we do not know if the data acquisitions took place during any high and/or low tides this value may only represent the lower limit of the tidal range.

\subsection{Ice thickness}

In order to compare ice thicknesses measured in radio echo soundings with an ice thickness computed from the surface elevation, we have to assume a mean density. Doake (1984) determined the mean ice density in areas of surface melt on GeorgeVI Ice Shelf and found it to be $915 \mathrm{~kg} \times \mathrm{m}^{-3}$

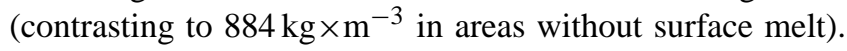
Zotikov et al. (1980) found the density of marine ice to be $927 \mathrm{~kg} \times \mathrm{m}^{-3}$. We assume that even in the case of brine infiltration the effect of salinity is rather small and thus we assume a mean ice density across the ice shelf of $915 \mathrm{~kg} \times \mathrm{m}^{-3}$. In hydrostatic equilibrium the ice thickness $H$ is derived from the surface elevation $h$ from

$H=\frac{\rho_{\text {sw }}}{\rho_{\text {sw }}-\bar{\rho}_{\text {ice }}} \times h$

where $\rho_{s w}$ denotes the density of sea water $\left(1027 \mathrm{~kg} \times \mathrm{m}^{-3}\right)$ and $\bar{\rho}_{\text {ice }}$ the mean density of ice.
Figure 3 displays the radio echo sounding ice thickness data obtained in 1966/67, 1969/70, 1971/72 and 1974/75 by the British Antarctic Survey. References to the field campaigns can be found in the BEDMAP database and Lythe et al. (2000).

In general, the ice thickness computed from freeboard heights under the assumptions made above agree well with ice thickness measured in the RES campaigns from 1969 to 1975 (Fig. 3). This statement rises and falls of course with the assumption made about the ice densities, so that no differences on the order of a few meters could be determined based on these estimations.

\subsection{Structural mapping}

\subsubsection{Ice front position}

WIS has experienced discontinuous mass loss in retreat and break-up events separated by stable years. For the period 1986 to present, more than 30 images have been used to detect the ice front positions. Scambos et al. (2000) already stated that the positions of the northern and north-western ice front were stable between 1947 and 1986 based on a map of the American Geographical Society showing the ice front from 1947 and historic maps and imagery of the Defense Intelligent Satellite Program from 1961. Figure 4 displays the northern and north-western ice front in selected years. From this record we address only time-spans when significant area change was observed. The northern ice front lost about $97 \mathrm{~km}^{2}$ in 1986-1990. A break-up (inference from shape and distribution of icebergs) $655 \mathrm{~km}^{2}$ broke off between 1990 and 1991. In 1993, another break-up event took place, separating $544 \mathrm{~km}^{2}$. This result is in reasonable agreement with the $564 \mathrm{~km}^{2}$ found by Lucchitta and Rosanova (1998). A large break-up event started in beginning of February 1998 and the changes are quite visible in Figure 4d-e showing imagery during and after the event. Our measurements of about $1100 \mathrm{~km}^{2}$ compare well to the loss of $1098 \mathrm{~km}^{2}$ given by Scambos et al. (2000) for March 1998, although an exact ice front is difficult to draw in the heavily fractured area. On the north-western ice front between Charcot and Latady Island repeatedly smaller quantities were lost from 1992 to January 2008. Pronounced area changes occurred between 1990-1993 $57 \mathrm{~km}^{2}, 1998-1999$ with $20 \mathrm{~km}^{2}, 1999-2000$ with $87 \mathrm{~km}^{2}$, 2001-2003 $52 \mathrm{~km}^{2}$ and 2003-2004 $51 \mathrm{~km}^{2}$. Changes on the south-western ice front between Latady Island and Lewis Snowfield amount to $196 \mathrm{~km}^{2}$ between 1990 and 2004. WIS is apparently an ice shelf that produces icebergs at a comparatively low rate under normal circumstances, but has experienced several break-up events, during which iceberg production increased enormously. Lucchita and Rosanova (1998) discussed the possibility of a retreat due to minimal extent of sea ice along the northern ice front. Visual inspection of MODIS images from 2002 to 2007 showed that 

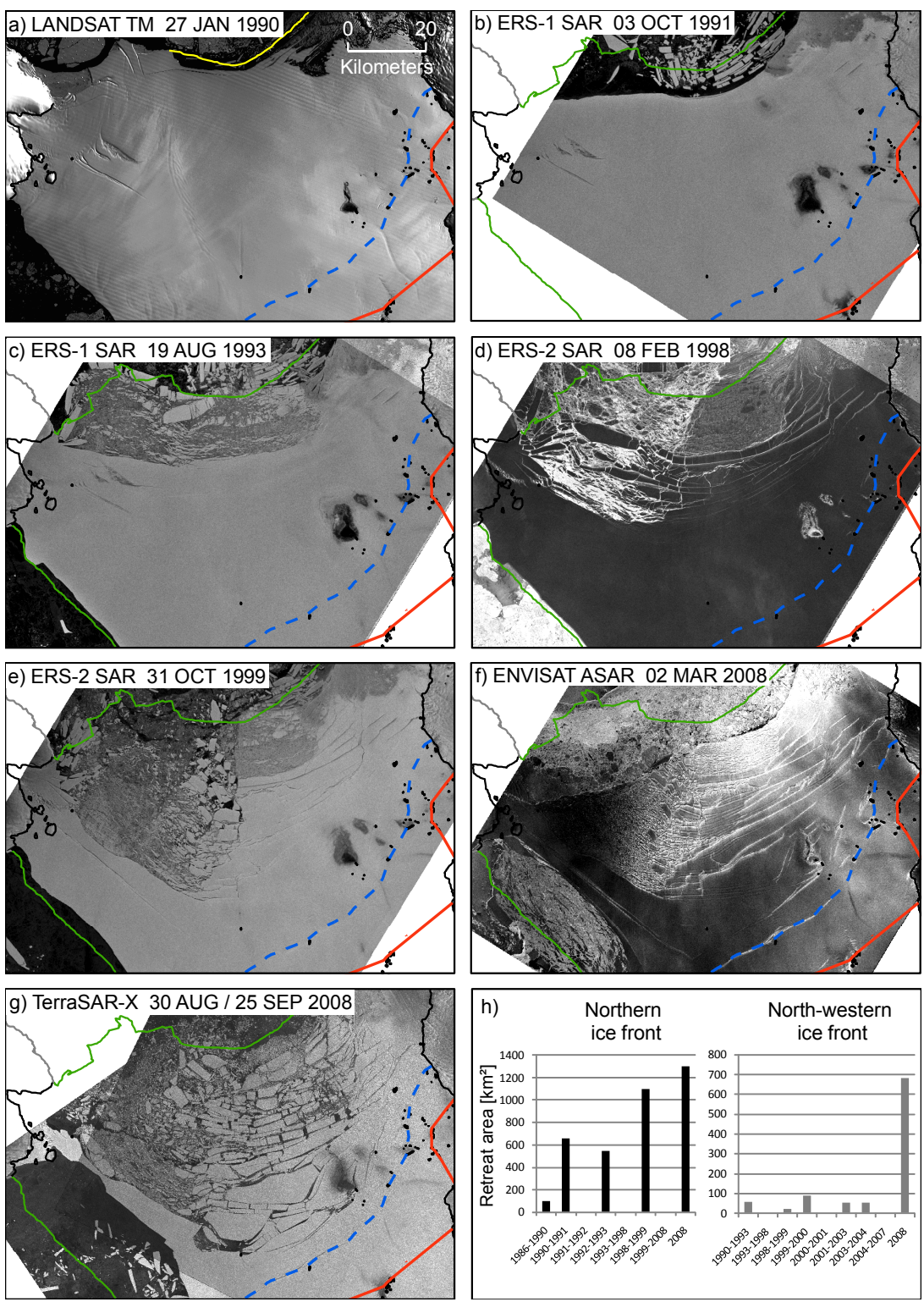

Fig. 4. Ice front position changes between 1990 and 2008. The ice front position of 1986 Landsat image is indicated as solid yellow line in (a). (b to g) show the ice front position from 1990 (solid green line) as reference. The dashed blue line displays a possible future ice from position based on the September 2008 fracture extent. The worst case scenario (see main text) is drawn in a red solid line. (h) points out the size of area loss and break-up events. (C) belongs to ESA for the ERS-2 and ENVISAT imagery, to DLR for the TerraSAR-X datasets.

the sound was free of sea ice in some of these years, while the northern ice front has not retreated during that time.

The break-up events on 28/29 February 2008 (about $425 \mathrm{~km}^{2}$ ) and 30-31 May 2008 (about $160 \mathrm{~km}^{2}$ ) are discussed by Braun and Humbert (2009) and will also be taken up partially in Sect. 4.2. In July 2008, another major mass loss occurred on the northern ice front where about $1220 \pm 75 \mathrm{~km}^{2}$ of the ice shelf plate were separated (Humbert and Braun, 2008).

\subsubsection{Particularities of WIS}

In Fig. 5 we provide a structural glaciological map of the entire WIS similar to the maps produced by Glasser and Scambos (2008) for Larsen B Ice Shelf. A zone of intense surface melting at the northern ice front is covered by melt ponds that are interconnected. The size of the area was in 1990 about $400 \mathrm{~km}^{2}$. Another area with intensive surface melt features exists on Haydn Inlet, the tributary glaciers from Alexander Island and in Schubert Inlet. Pronounced pressure ridges can be identified at the eastern inflow of 


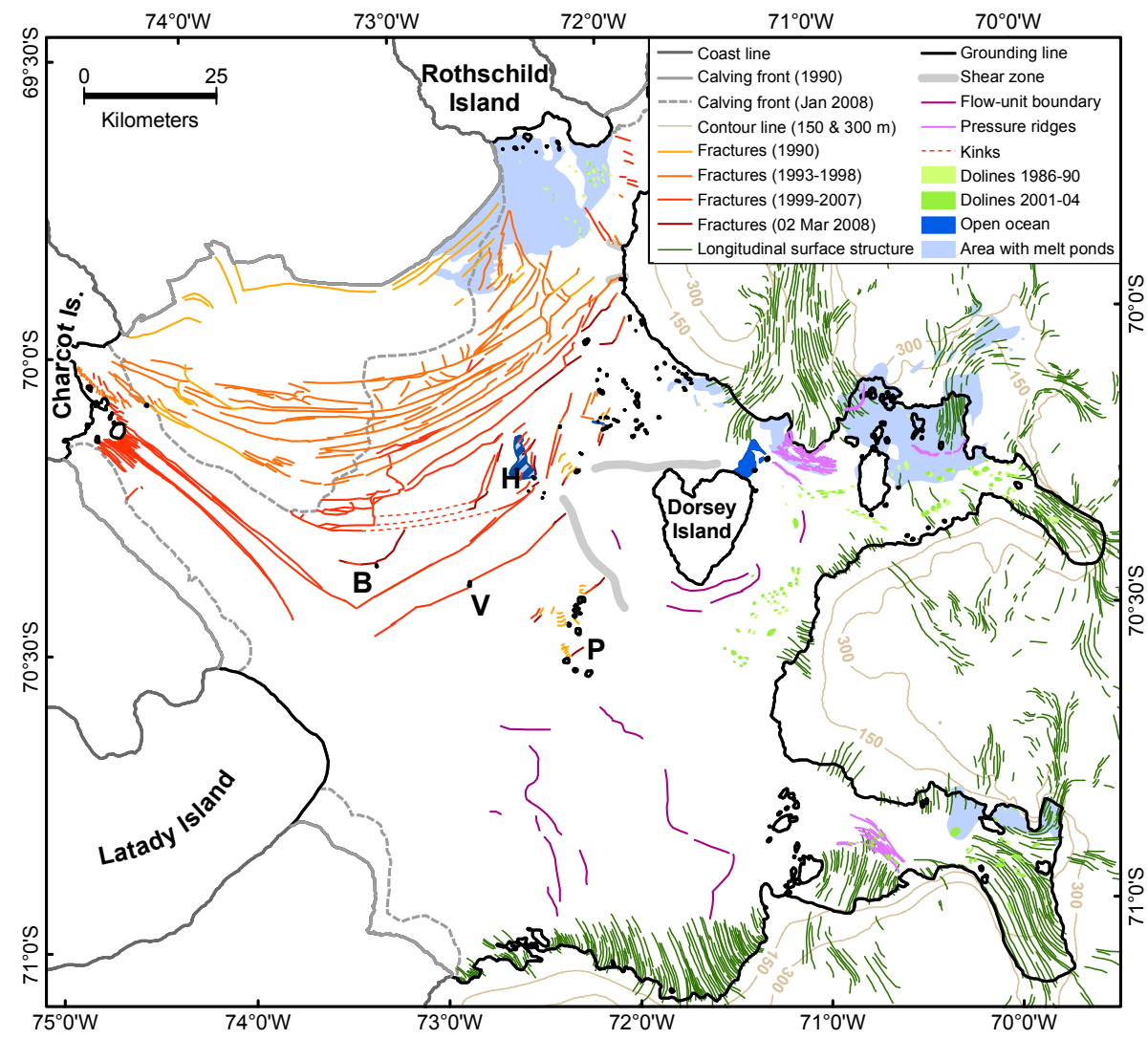

Fig. 5. Structural glaciological map of Wilkins Ice Shelf as revealed by image interpretation of various remote sensing data sources. Elevation contours on Alexander Island were generated for $150 \mathrm{~m}$ and $300 \mathrm{~m}$ contour from the Radarsat Antarctic Mapping Project Digital Elevation Model version 2 (Liu et al., 2001).

Gilbert Glacier as well as at an inflow area into Schubert Inlet. Longitudinal surface structures on the ice shelf and tributaries resulting from ice flow are indicated with green lines.

We also detected zones with a high density of dolines. Dolines are round, hollowed depressions with horizontal dimensions in the order of a few hundred meters. We estimate the number to about 85 from the Landsat (1986-1990) and to more than 100 of these surface structures from the ASTER mosaic (2001-2004). However, the unique identification is often limited by the spatial resolution of the imagery, so that these numbers should be accounted as guideline values. Bindschadler et al. (2002) found that dolines on the Larsen Ice Shelf occur almost only in floating areas and solely in combination with melt ponds. In contrast to them, we found dolines also off melt pool areas. However, the two most prominent areas with melt ponds are doline-studded as well. According to Bindschadler et al. (2002) the formation of ice dolines is most probably caused by surface melt water creating voids and subsequent collapse. These authors showed that the formation can happen very quickly and dolines can exist then over various years. Hence, the increase in number of dolines might be associated with the extent and intensification of surface melt although a proof for this cannot be provided.

Figure 5 displays also an area of about $15 \mathrm{~km}^{2}$ of open ocean between Dorsey Island and the adjacent coast of Mozart Ice Piedmont. Swithinbank (1988) identified this as a $2 \times 2 \mathrm{~km}$ lake. Open ocean in this form is only rarely found on ice shelves, and only where massive, fast flowing ice streams enter the ice shelf. Here, the presence of a large ice rise acts to support the formation of open water.

Burgess Ice Rise (area of $0.073 \mathrm{~km}^{2}$, see Figs. 5, 6a, denoted as B), although named ice rise, is presumably an ice rumple as visible imagery reveals. Ice rumples differ from ice rises as the ice flows across them and the strain energy is presumably relieved predominantly by recrystallisation. We suppose that the recrystallisation leads to the formation of a downstream plastic zone, which we found not to be intersected by rifts and thus we conclude that it is not a failure zone that weakens the ice shelf. The zone is, however crossed by kinks formed by ice front deflection (Fig. 5). These kinks are detectable in visible and SAR imagery (see arrows in Fig. 6a) and the analysis of ICESat surface elevation data 
revealed an elevation change of only $0.5 \mathrm{~m}$ in these kinks.

The location of the downstream zone is coincident with the eastern margin of the triangular-shaped area that broke off in the 1998 event. Thus, the plastic zone stopped further break-up and stabilized the ice front. The prolongation of this zone downstream of B is indicated by black lines in Fig. 6a.

Two types of fracturing exist in ice shelves: mode $1 \mathrm{cracks}$, where the crack surfaces move apart (Gross and Seelig, 2006). This crack mode originates from tensile stress and is often evident on ice shelves that exhibit crevasses parallel to the ice front. Contrastingly, mode 2 cracks are formed from shear stress and lead to crack surfaces sliding past each other (shear-mode). Cracks of this mode, aligned in flow direction, are found between fast flowing ice streams and slow moving areas (e.g. Stancomb-Wills Ice Stream on Brunt Ice Shelf - Stancomb Wills Ice Tongue System). Glasser and Scambos (2008) showed that on the Larsen B Ice Shelf, these lines preconditioned the ice shelf for break-up.

Figure $6 \mathrm{~b}$ shows a TerraSAR-X scansar image from 20 April 2008 of the eastern part of the northern ice front, where a glacier is draining from the Mozart Ice Piedmont into the ice shelf. Shear rifts mapped in the Landsat image from 1990 are displayed in blue colour. Those rifts moved with the ice flow downstream and experienced tensile stress, which is verified by their new shape in form of a wing crack.

Furthermore, the 1990 image shows short rifts originating from tensile stress acting on the ice front, which are shown as green lines. Those rifts were elongated by subsequent breakup events.

The upper part of Fig. $6 \mathrm{~b}$ shows a dark zone with melt-ponds (see also Fig. 5a). Propagation of the tensile mode rifts is hindered there by a region of high compressive stress in the vicinity of Rothschild Island. Since regions of high compressive stress are known to limit crack propagation (Gross and Seelig, 2006), we suggest that this is the reason for the persistence of this area against fracturing. WIS exhibits in the centre a dark area, which was formerly identified by Lucchita and Rosanova (1998) as a melt pool (see Fig. 1, "H"). They also report that the size has not changed between the 1990 Landsat and the 1992 ERS image. Swithinbank (1988) saw this feature present already in a Landsat image from 1979. In Fig. 6c we show a TerraSAR-X image of this area from April 2008, while Fig. 6d displays the same area after the June/July 2008 break-up in a TerraSAR-X scansar image from 30 August 2008. Both panels also display the surface elevation of an ICESat track. The general flow direction is outlined with three black arrows. The lower two arrows correspond to inflow from Handel Ice Piedmont (see Fig. 1), the right one to the inflow from Gilbert Glacier. Figure $6 \mathrm{c}$ discloses open ocean in a rift (which we denote from here on H-rift). This open ocean is surrounded by ice with lower SAR backscatter (in either L- or C-Band), which is presumably a sign of refrozen melt water. The entire area of " $\mathrm{H}$ " has a lower elevation than the surrounding ice shelf (Vaughan et al., 1993), which is typical for lee-sides of ice
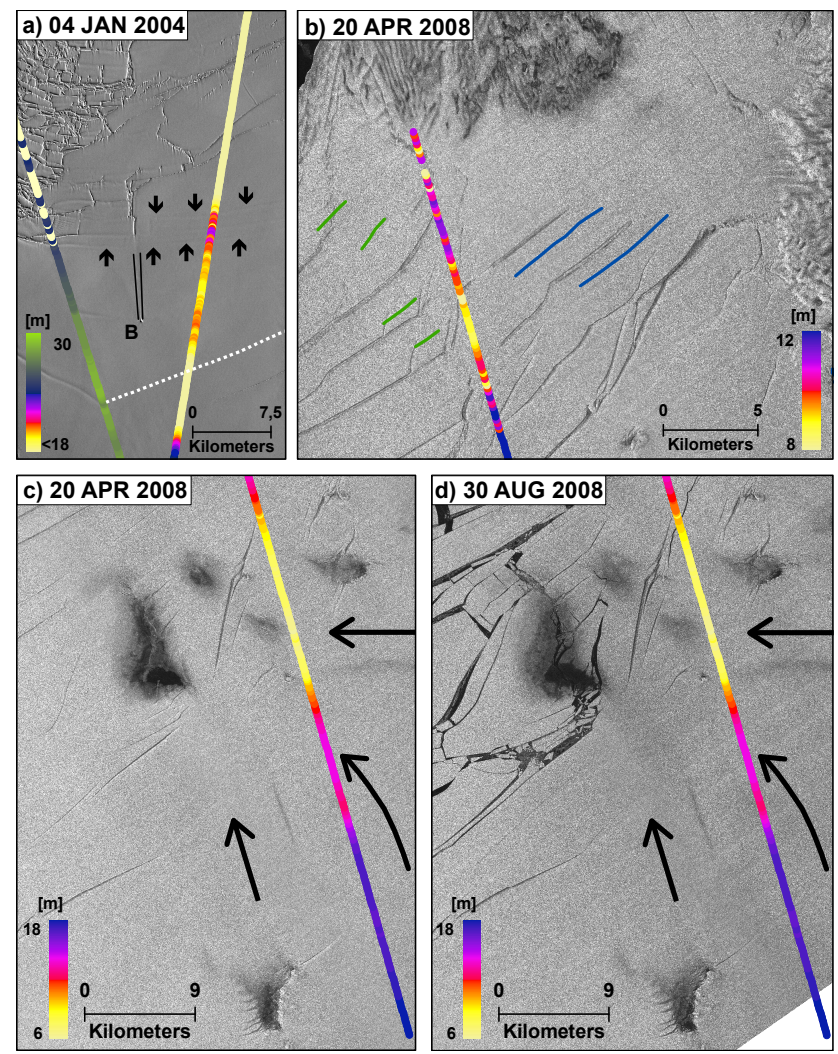

Fig. 6. Structural mapping of rifted areas: (a) ASTER images (C) USGS) showing that Burgess Ice Rise (B) is forming a zone of plasticity downstream, which is marked here with black lines. This zone is not crossed by rifts, only by kinks from ice front deflection, marked with arrows. The kinks are visible in ICESat surface elevation. The dotted line marks a connection between the rift at its left end and rifts in the vicinity of the open water area shown in (c) and (d). (b) Shear zone in the vicinity of the surface melt area along the eastern end of the northern ice front in a TerraSAR-X scansar image from 20 April 2008. The blue lines are shear rift locations and the green ones rifts caused by tensile stress, both in the 1990 Landsat image. Superimposed is an ICESat GLAS track with freeboard heights in colour. (c) TerraSAR-X scansar image from 20 April 2008 showing the area of open water and melt feature denoted as "H" already in Vaughan et al. (1993). The flow direction is indicated by black arrows. The mean ICESat surface elevation is superimposed. (d) TerraSAR-X scansar image from 30 August 2008 showing the same area as in (c) after the break-up event in June/July 2008. (C) DLR for all TerraSAR-X imagery.

rises. The size of the open ocean surface is $3820 \mathrm{~m}^{2}$, in a total area of surface melt of $4.1 \mathrm{~km}^{2}$.

The formation of open water is caused by two flow units joining at a location of a set of small ice rises. The already damaged ice structure, easily allows the formation of a through-crack. The fixed location of the ice rises and the shear margins are the reason why this feature persisted for such a long time. Propagation of the H-rift toward the ice front is further promoted by tensile mode fractures at ice 

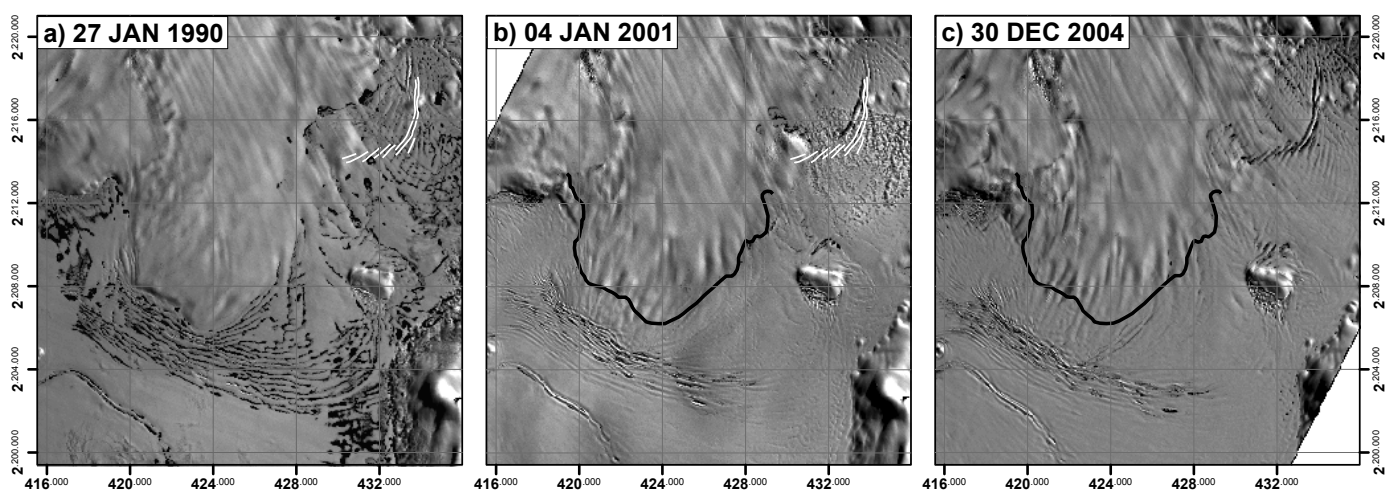

Fig. 7. Advance of Gilbert Glacier into Haydn Inlet. In all images the terminus position is well marked by pressure ridges partially filled by melt water ponds. Black lines indicate the terminus position from the Landsat image from 1990, whereas white lines denote the pressure ridges mapped in the ASTER (C USGS) image from 2004. Coordinates are given in UTM projection; grid lines have $4 \mathrm{~km}$ spacing.

rises east to the open water area, along which the H-rift is meandering. The meandering of the $\mathrm{H}$-rift was not seen in the 1990 image. In the 1990 image, i.e. before the first recorded break-up event, those fractures were only of the width of the ice rises. The tensile mode fractures at the ice rises east of " $\mathrm{H}$ " were formed in connection with break-up events at the ice front, not by ordinary flow divide around ice rises. The detection of the force which caused the crack faces to move apart and thus initiated the propagation, however, requires a modelling of the stresses from ice creep. Figure $6 \mathrm{~d}$ reveals that the June/July 2008 break-up separated the ice masses along the $\mathrm{H}$-rift.

\subsubsection{Advance of Gilbert Glacier}

Gilbert Glacier is one of the most prominent tributaries of WIS. It drains the northern mountain ranges of Alexander Island towards the South (Fig. 1). Near WIS, the glacier is split by a bedrock outcrop into two tongues, one ending in Haydn Inlet, one ending north of the open water area described in Sect. 3.5.2 and Fig. 5. The southern terminus position of Gilbert Glacier is well marked by shading effects and a pattern of pressure ridges emphasised by intersected melt water ponds (Fig. 7a). As can be see in the subsequent time steps of this figure, the pressure ridges have been considerably relocated by an advance of the Gilbert Glacier tongue into Haydn Inlet. Between 1990 and 2001, the main tongue advanced by about $1.3 \mathrm{~km}$ and until 2004 the advance amounts to almost $2 \mathrm{~km}$, indicating an acceleration of this process. Interestingly, a closer analysis reveals that particularly the southern tongue advanced and that the pronounced shear margin of the northern tongue is relocated northwest by approximately $1.9 \mathrm{~km}$ due to the massive inflow. The pronounced bend of this shear margin is changed and relocated north-west-wards.
The limited database does not allow determining the reason for the advance. Analysis of the multi-spectral imagery upstream does not reveal any indications of significant surface lowering, intensified crevasse patterns or changes in surface melt features. However, this observation is consistent with reports from sites further north on the Antarctic Peninsula. Impressive glacier retreat along the west coast of the Antarctic Peninsula was documented by Rau et al. (2003) and Cook et al. (2005). Pritchard and Vaughan (2007) showed widespread acceleration of tidewater glaciers on the west coast of the Antarctic Peninsula, which they mainly attributed to a dynamic response to frontal thinning. H. D. Pritchard (personal communication, 2008) estimates the dynamic surface lowering to about 1 to $3 \mathrm{~m} \mathrm{a}^{-1}$ (from 2003 to 2007) for glaciers near Wilkins Ice Shelf.

\section{Discussion}

\subsection{Evolution of failure zones}

In general, nuclei for the evolution of failure zones are ice rises and shear margins. The latter is under-represented on the WIS and will thus not be discussed further in the following.

Ice rises are small areas where the floating ice shelf is grounded. Depending on their size, they have typically a dome-like surface topography. They divide the ice flow and thus they induce general lower ice flow speeds. The WIS has an extremely large number of ice rises: namely 172 , most of them are small, with a width $<2 \mathrm{~km}$. Upstream of ice rises the ice is piled up and the surface is upfolded. Visible imagery of the lee-side shows that the ice shelf is more crevassed, for some ice rises even filled with a melange of ice. At these locations, double-differenced interferograms (not shown here) do not show a typical pattern 
of tidal deflection normally apparent by a dense sequence of interferometric fringes. Hence, this indicates that no hinge zone is developed here.

Ice rises were for a long time supposed to stabilize ice shelves, as they act as pinning points (e.g. Hughes, 1983) when they are located at the ice front. Modelling studies of the Ross Ice Shelf have shown that the ice rises are able to form flow units and, depending on their distance to the grounding line decouple flow and form inactive flow zones (Humbert et al., 2005). Modelling studies of the Brunt Ice Shelf revealed a strong effect of a cluster of small ice rises (McDonald Ice Rumples) at the ice front on the ice flow direction of the whole ice shelf (Humbert and Pritchard, 2006) and furthermore, they are known to control the evolution of the ice front (Simmons, 1986).

Ice rises are, on the other hand, also a well known feature for formation of failure zones, like the rifts formed when the ice flow divides around them. In these areas, bottom crevasses are also formed (see e.g. Shabtaie and Bentley, 1982). The size of the rifts is normally in the order of the size of the ice rise itself. In the 1990 Landsat image, most of the ice rises were accompanied by such small rifts.

As ice shelves spread out towards the ice front the stress regime is in most parts a tensile stress regime rather than a bending stress regime. Thus, the previously formed fractures in the vicinity of ice rises, which are supposed never to heal completely, experience the tensile stress and ordinary calving occurs. This happens on time quasi-static periods, which is of the order of the surrounding flow speed and thus meters per year.

Contrastingly, we also observed drastic fracture evolution and extension: after the 1998 break-up event a $44 \mathrm{~km}$ long double rift (tensile mode) appeared on the connection to Charcot Island and extended by $9 \mathrm{~km}$ in 2001 and $3 \mathrm{~km}$ in 2008. At Vere Ice Rise a $4 \mathrm{~km}$ long rift (tensile mode) is firstly detectable on 8 February 1998 and had extended by $15 \mathrm{~km}$ on 31 October 1999. A further elongation of $5.5 \mathrm{~km}$ was mapped on an image from 2004. On 23 November 2008 a new fracture ( $32 \mathrm{~km}$, tensile mode) has formed south of the rift at Vere Ice Rise. These examples show that the time scale on which the evolution of failure zones is happening is not quasi-static, but dynamic.

Hence, ice rises are, in the absence of a compressive stress zone that hinders rift propagation, a destabilising factor. Doake and Vaughan (1991) also mention ice rises as aiding destruction of ice shelves, as rifts formed in the vicinity of ice rises on Wordie Ice Shelf stretched upstream in flow direction. This mechanism is, however, different from their role on WIS.

WIS is however not representative for ice shelves in general, since an unusually large number of ice rises exist there. Thus, our findings do apply to ice shelves with similar conditions only. One example was to be found in the eastern Pine Island Bay (Uenzelmann-Neben et al., 2007), where ice retreat since the Last Glacial Maximum uncovered a highly uneven sea-floor with many small islands. This area of high ice rise density has disintegrated completely.

\subsection{Stabilizing connection to confining islands}

In Fig. 8 we focus on a sensitive area that connects the central ice shelf to the Charcot and Latady Islands. This $1025 \mathrm{~km}^{2}$ (2006) large area is of great importance to the main ice shelf, as it is supposed to act stabilisingly and inhibiting a catastrophic retreat of the northern ice front. Panel 8a displays the situation in January 1990. The connection is more than $20 \mathrm{~km}$ wide before the first rifts appear. The major break-up event in 1998 reduced the connection considerably and a major tensile mode rift formed at an ice rise in front of Charcot Island. Moreover, the western ice front was also subject to calving leaving a rifted connection of about $18 \mathrm{~km}$ width. Two ICESat GLAS tracks are superimposed in panel $\mathrm{b}$ and the respective elevation profiles are shown in Fig. 8d. The depth of the rifts is clearly captured by the laser altimeter. The grey bars mark the position where a new tensile mode rift formed in 2007, depicted very well in the ALOS PALSAR image (Fig. 8c). The small subset highlights the sensitive connection to Charcot Island where numerous small fractures have formed. This stripe-shaped connection is formed by ice of a variable thickness as can be seen in Fig. 3. In RES surveys, this area did not have return signals, which indicates that there is brine infiltration across the whole ice connection. The ice on the connection between Charcot and Latady islands is in the on the western side considerably thinner $(\leq 170-190 \mathrm{~m})$ than in the middle $(\sim 250 \mathrm{~m})$. Therefore, buoyancy forces vary across the ice stripe and induce a bending stress perpendicular to the rift seen in Fig. 8c. Assuming a parabolic upper and lower surface and an ice draft at the sea side of $100 \mathrm{~m}$, the bending stress can be estimated to be $11 \mathrm{MPa}$ and thus two orders of magnitude larger than the stress from ice creep. The stress was released by brittle fracture formation, which propagated presumably with Raleigh wave speed and hence took place in a time scale of minutes.

The break-up event starting on 28 February 2008 is shown in Fig. 8e. Several blocks broke out at the ice shelf front near, but not directly at Charcot Island. The ASTER subset shows that additional longitudinal rifts have formed. Until 29 February, almost the entire ice towards the fracture from 2007 was lost, and until 7 March an area of about $425 \mathrm{~km}^{2}$ broke off leaving only a very narrow connection of about $6 \mathrm{~km}$ width to Charcot Island. The remaining connection was fractured by the 1998 event and also exhibits already small fractures where it is tied to the ice rise in front of Charcot Island.

The uncalibrated thermal MODIS image from 28 July 2007 (available at: http://nsidc.org/data/iceshelves_images/ wilkins.html) shows significant temperature differences between the rifts (formed in 1998) and the undamaged surrounding ice. This can only be understood when warm 


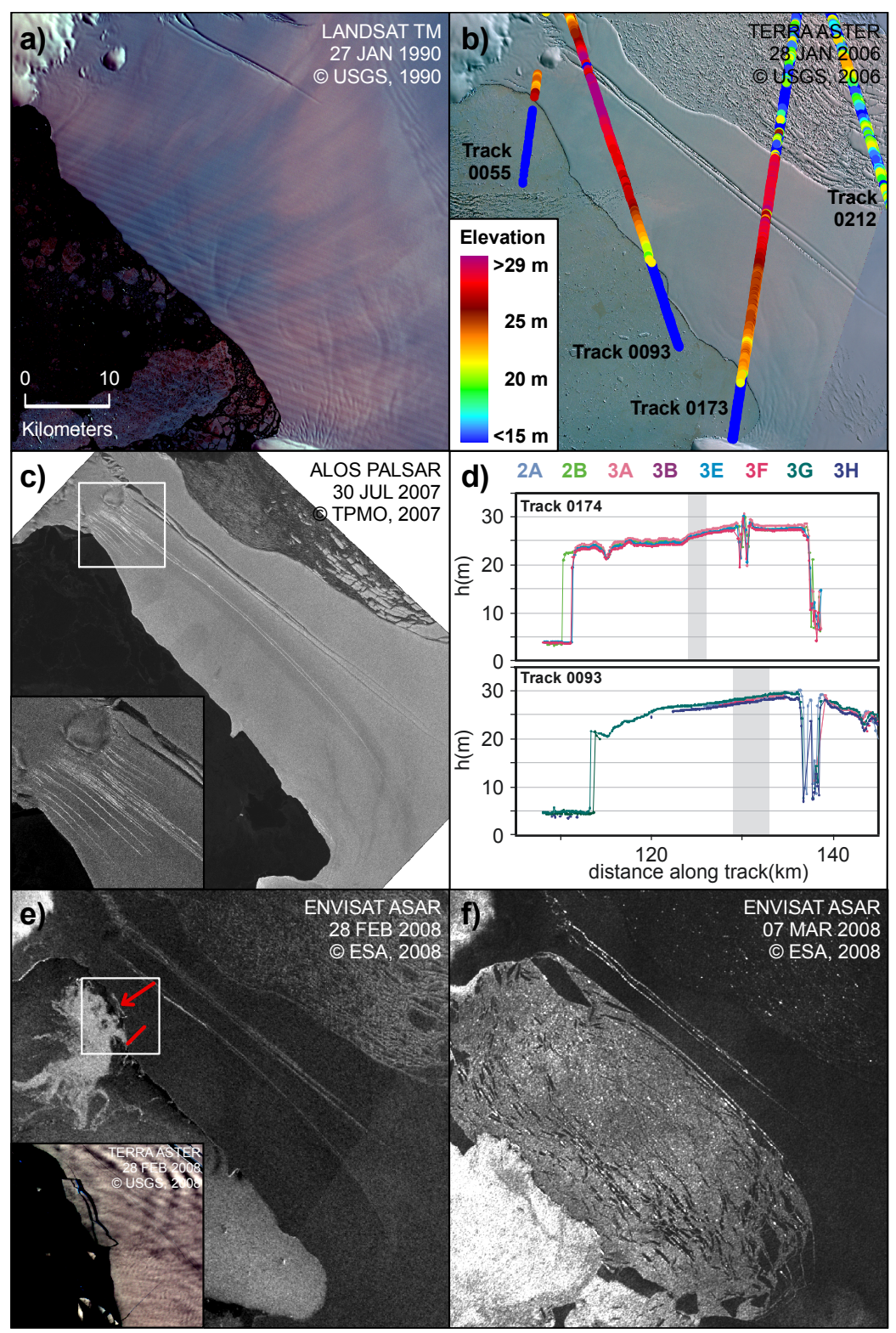

Fig. 8. Connection between Charcot and Latady Islands that has experienced the break-up events in February and May 2008. The Landsat image from 1990 (a) shows the area that has been reduced to its present form in shape of a stripe in 1998, as can be seen in the Terra ASTER image from 2006 (b). Tensile mode rift formation in an ALOS PALSAR image from July 2007 (c) prior to the break-up event shown in (e) and (f). (d) displays surface elevation of the two tracks superimposed in (b). The grey bars denote the location where the rifts in July 2007 were formed. This fracture was measured to be $52 \mathrm{~km}$ long.

ocean water fills a rift up to sea level. We can exclude heat conduction between the underlying ocean and the hypothetical unfractured lower ice mass because the time scales of heat conduction are several magnitudes larger than the period over which the warm temperature signatures appeared after rift formation. Thus, the bottom part, even if not intersected by a large crack, does have at least small cracks, that accomplish a connection to the ocean. Intruding sea water has a higher temperature than the surrounding ice and will heat up the bulk ice mass at the sides of the crack, and hence further weaken the mechanical strength of the ice.

The break-up event in February 2008 resulted in intensive monitoring of the region by satellites. An ENVISAT ASAR image from 30 May 2008 shows the beginning of another break-up event. On the connection between Latady and Charcot Islands further $160 \mathrm{~km}^{2}$ were lost, forming an ice front coincident with the rift from 1998. This break-up, as well as the February 2008 break-up, is a consequence of the 
rift formation caused by bending stresses. These events are discussed in more detailed by Braun and Humbert (2009).

It is remarkable that the 1998 break-up event also started at the stripe between Charcot and Latady islands. In the 1980s, the ice was comparably thick in that area (GEOSAT data, Vaughan et al., 1993). There, inflow from Charcot Island caused shear-mode cracks. Those cracks existed by 1990, but the situation remained nevertheless stable for several years. We speculate that basal melting has thinned the boundaries and thereby emerging bending stresses from buoyancy forces were also the cause for the 1998 break-up.

\subsection{Changes of WIS in the past 15 years and their likely} causes

Since 1990, WIS has undergone great changes. In 1990 the central area did not have any rifts. The only detectable weak zone was the open water area (H in Fig. 1). In 1993/94, rift formation started to advance at the northern ice front. Today, the central area is intersected with rifts in the order of tenths of kilometres in length, which have already coalesced.

The sections above showed that we have identified nuclei for failure zones like ice rises and shear zones and additionally rift formation by buoyancy forces. We conclude that the break-up events themselves are connected to the pre-conditioning by failure zones.

We aim to assess all considerable causes for the changes and exclude first those which to current knowledge did not contribute:

- The inflow from inlets was always inhibited by ice rises that block the outflow into the central ice shelf. Thus, we can exclude that once they played a significant role.

- For WIS no repeated measurements of surface accumulation exist. Although, Thomas et al. (2008) compiled evidence that an increase of surface accumulation occurs in higher elevations on the South-Western Antarctic Peninsula, it remains unknown if and how this applies to WIS. Hence, there is so far no evidence for a considerable change in surface accumulation pattern or magnitude.

- Changes in inflow: although we found in 3.5.4 an area where changes in glacier inflow are significant, their effect on the central ice shelf is insignificant, because it affects one inlet and we discussed above that the inlets play only a minor role in the dynamics of the central ice shelf. Manual feature tracking revealed that the interferometric flow field of the central ice shelf seems to remain valid. Hence, we infer, that changes in the inflow are unlikely the explanation for today's situation of WIS.
- Although we know that the number of degree days has increased, we see that the area of melt ponds remained the same since 1986. Melt ponds aroused suspicion to cause ice shelf disintegration in combination with pre-existing crevasses (Scambos et al., 2003). Most of the melt-pond area at the northern ice front still exists. We infer that the existence and formation of melt ponds is not responsible for the changes and even more, that melt-pond drainage into crevasses played no role in all break-up events on WIS. However, it is not excluded that melt water has an influence different from this one.

The following factors cannot be excluded and thus, might have led to changes of WIS in the past decade:

- Increased basal melting: WIS is particularly sensitive to changes in basal melt rates, as it is thin and mass gain is not dominated by glacier inflow, but rather by in situ accumulation. Today, the widely rifted area in the central ice shelf is also an area of low surface elevations and therefore, thin ice thickness. Dinniman and Klinck (2004) have shown the potential of warm water masses to flow across continental shelf break, Bathymetry of the Bellinghausen Sea (Bolmer et al., 2004) demonstrate a trough between Latady and Charcot Island, and a continental shelf break (GEBCO), possibly allowing warm water masses to enter the WIS sub-ice shelf cavity. Meredith and King (2005) reported the occurrence of increased summer water temperatures on the Western Antarctic Peninsula. Variations in basal melt rates would thus be a plausible explanation for the observed changes. A proof is, however, impossible without detailed analysis of variations in the mass balance. Since the required datasets are not available for the late 80 s and early 90s, such an analysis is not accomplishable.

- Exceeding of a critical limit in material parameters: the complete area covered by today's failure zones, showed evidence for brine infiltration in radio echo soundings. Furthermore, brine infiltration in combination with large surface accumulation form an ice mass that does likely not consist of pure meteoric ice but an ice matrix with brine pockets. Its high surface temperature suggests the WIS consists mainly of warm ice. The tensile strength of polycrystalline ice rises by approximately $25 \%$ upon decreasing temperature from $-5^{\circ} \mathrm{C}$ to $-20^{\circ} \mathrm{C}$ (Schulson, 1999). Both factors, salinity and temperature, are known in sea ice to determine the mechanical strength (e.g. Weeks and Ackley, 1982). We infer that both factors also contribute to the mechanical strength of WIS as well. Thus, it has to be considered, that rising water temperatures led to an increased temperature of the bulk ice mass and that the mechanical strength fell below a threshold, easing crack formation. Temperature dependent fracture toughness 
has also previously been proposed by Vaughan and Doake (1996) as a possible reason for ice shelf disintegration.

Unfortunately, these are only speculative ideas of what exactly WIS has experienced, since there are too few observed variables accessible over the last 15 years. This exemplifies the need for continuous acquisition of at least a basic set of glaciological variables, including ice thickness, speeds, surface accumulation, temperatures and oceanic variables that allow verifying or falsifying assertions and establishing general statements.

\subsection{Fate of WIS}

To date (February 2009) the connection between Charcot and Latady Island is only $900 \mathrm{~m}$ wide at the narrowest location and we expect a collapse in the near future. The fracturing of the northern part of WIS makes it most likely, that the collapse of the ice bridge would cause larger ice masses in this area to be separated as well. Without modelling of the stresses in the entire ice shelf, a prediction of the existence and the location of a future stable northern ice front remains vague. However, we expected compressive stresses to be built up between Latady Island, Petrie Ice Rises and Dorsey Island. Thus, at most further $3100 \mathrm{~km}^{2}$ are suspected to be lost, while we expect $8000 \mathrm{~km}^{2}$ of the original $13000 \mathrm{~km}^{2}$ to remain intact.

\section{Conclusions}

This study revealed that WIS has undergone significant change in the past two decades. The central part of WIS is today intersected by long rifts that are formed in pre-conditioned failure zones around ice rises.

The recent break-up has left only a very narrow; already fractured connection in a sensitive area that is stabilizing the northern part of the ice shelf. Furthermore, a new rift connection formed between already existing fractures, crossing almost the entire northern shelf, which makes WIS even more fragile and vulnerable. Today, we expect at most another $\sim 3100 \mathrm{~km}^{2}$ of the original $13000 \mathrm{~km}^{2}$ of WIS, are at risk if this connection to Charcot Island will be lost.

Buoyancy forces were responsible for tensile mode rift formation before the recent break-up in end of February 2008. We infer, accumulation of bending stresses from buoyancy forces, e.g. by enhanced basal melting at ice fronts or coalescing flow units, is a considerable factor for ice shelf break-up, in particular because of the short timescales of its sudden release.

We show that the evolution of failure zones has component of discontinuous, fast development. The evolution of failure zones can be constrained by zones of high compressive stresses. We found evidence that the presence of ice rises in the ice shelf produce areas of weakness, along which failure can occur when break-up events begin. This can be assumed to be another process inducing ice shelf disintegration.

Our findings are different to the observations by Glasser and Scambos (2008) on Larsen-B Ice Shelf who found, that failures along weakly sutured flow-unit boundaries of the fast flowing tributaries were particular important and that the retreat of the ice front removed the strongest part of the ice shelf. Furthermore, they compile evidence that acceleration of tributary glaciers prior to collapse may have occurred. This exemplifies the different initial situations of these two ice shelves, both leading to break-up.

This study points out the importance of an investigation of the material condition of the ice of WIS, like the fracture toughness and viscosity. This is of particular relevance, since the WIS consists of a bulk mass of warm ice, where decreased fracture toughness and increased liquidity compete. Further remote sensing analysis should address kinematics of the ice shelf and its tributaries as well as their possible variations, in particular for areas where such information is not available so far. Any in-situ measurements (e.g. basal melt rates, density, accumulation, velocities) would considerably support further integrated remote sensing analysis as well would do a better understanding of ocean circulation and its changes in that part of the Antarctic Peninsula. It is beyond doubts that monitoring WIS and its tributaries in near future is worthwhile and will certainly bring further understanding of the mechanisms leading to ice shelf break-up.

The multi-sensor approach provided sufficient datasets (horizontal speeds, grounding lines, ice thickness) so that future modelling of WIS has now a profound base, enabling sensitivity experiments to study the effects of failure zones, increased surface temperatures and basal melt rates with the aim to answer the question what caused the changed dynamic state.

Acknowledgements. M. B. and A. H. acknowledge support by the German Research Council under grants BR 2105/4-1-3 and HU 1570/2-1. We wish to thank Dietmar Gross and Ralf Mueller (Darmstadt University of Technology) for useful discussions on fracture mechanics and rift formation. The anonymous reviewers and the different online comments helped to improve the paper.

Data for this study was provided under ESA IPY AO 4032, AOALO 3575, CryoSat AO 1274 and DLR AO LAN_0013. The authors would like to thank NSIDC ICESAT and NASA Cryosphere Program for making the ICESat releases available and Christopher A. Shuman for support and discussion. We would like to thank Heinz Bennat and Jörn Sievers (Bundesamt für Kartographie und Geodäsie) for making Landsat imagery of the Geographic Information System of Antarctica available.

Edited by: J. O. Hagen 


\section{References}

Arendt, A. A., Echelmeyer, K. A,. Harrison, W. D., Lingle, C. S., and Valentine, V. B.: Rapid wastage of Alaska glaciers and their contribution to rising sea level, Science, 297, 382-386, 2002.

Arthern, R. J., Winebrenner, D. P., and Vaughan, D. G.: Antarctic snow accumulation mapped using polarization of 4.3-cm wavelength microwave emission, J. Geophys. Res., 111, D06107, doi:10.1029/2004JD005667, 2006.

Bassis, J. N., Fricker, H. A., Coleman, R., and Minster, J.-B.: An investigation into the forces that drive ice-shelf rift propagation on the Amery Ice Shelf, East Antarctica, J. Glaciol., 54(184), 17-27, 2008.

Bindschadler, R., Scambos, T. A., Rott, H. Skvarca, P., and Vornberger, P.: Ice dolines on Larsen Ice Shelf, Antarctica, Ann. Glaciol., 34, 283-290, 2002.

Bolmer, S. T., Beardsley, R. C., Pudsey, C., Morris, P., Wiebe, P., Hofmann, E., Anderson, J., and Maldonado, A.: A High-Resolution Bathymetry Map of Marguerite Bay and adjacent Western Antarctic Peninsula Shelf Southern Ocean GLOBEC Program, W. H. O. I Technical Report WHOI-2004-02, 2004.

Braun, M. and Humbert, A.: Recent retreat of Wilkins Ice Shelf revealing new insights in ice shelf break-up mechanisms. Geoscience Remote Sens. Lett., 6(2), doi:10.1109/LGRS.2008.2011925, accepted, 2009.

Clarke, A. Murphy, E. J., Meredith, M. P., King, J. C., Peck, L. S., Barnes, D. K., and Smith, R. C.: Climate change and the marine ecosystem of the western Antarctic Peninsula, Philos. T. R. Soc. B, 362, 179-166, 2007.

Comiso, J. C.: Variability and trends in Antarctic surface temperatures from in situ and satellite infrared measurements, J. Climate, 13, 1674-1696, 2000.

Cook, J. A., Fox, A. J., Vaughan, D. G., and Ferringo, J. G.: Retreating glacier fronts on the Antarctic Peninsula over the past half century, Science, 308, 541-544, 2005.

Cooper, A. P. R. and Hinton, J. C.: Correction of satellite radar altimeter data on ice-covered surfaces in Antarctica using an integrated Geographical Information System, Int. J. Remote Sens., 17(7), 1367-1376, 1996.

De Angelis, H. and Skvarca, P.: Glacier surge after ice shelf collapse, Science, 299, 1560-1562, 2003.

Dinniman, M. S. and Klinck, J. M.: A model study of circulation and cross-shelf exchange on the west Antarctic Peninsula continental shelf, Deep Sea Res. II, 51, 2003-2022, 2004.

Doake, C. S. M: Ice-shelf densities from a comparison of radio echo and seismic soundings, Ann. Glaciol., 5, 47-50, 1984.

Doake, C. S. M. and Vaughan, D. G.: Breakup of Wordie Ice Shelf, Antarctica, IAHS Publ., 208, 161-165, 1991a.

Doake, C. S. M. and Vaughan, D. G.: Rapid disintegration of the Wordie Ice Shelf in response to atmospheric warming, Nature, 350, 6316, 328-330, 1991b.

Doake, C. S. M., Corr, H. F. J., Rott, H., Skvarca, P., and Young, N. W.: Breakup and conditions for stability of the northern Larsen Ice Shelf, Antarctica, Nature, 391, 778-780, 1998.

Fox, A. J. and Vaughan, D. G.: The retreat of Jones Ice Shelf, Antarctic peninsula, J. Glaciol., 51(175), 555-560, 2005.

Glasser, N. F. and Scambos, T. A.: A structural glaciological analysis of the 2002 Larsen B ice shelf collapse, J. Glaciol., 54(184), 3-16, 2008.
Gross, D. and Seelig, T.: Fracture Mechanics: With an Introduction to Micromechanics, Springer, Berlin, Germany, 327 pp., 2006.

Harangozo, S. A., Colwell, S. R., and King, J. C.: An analysis of a 34-year air temperature record from Fossil Bluff ( $\left.71^{\prime \prime} \mathrm{S}, \mathrm{SSOW}\right)$, Antarctica. Ant. Sci., 9(3), 355-363, 1997.

Hughes, T.: On the Disintegration of ice shelves, J. Glaciol., 29(101), 98-117, 1983.

Humbert, A., Greve, R., and Hutter, K.: Parameter sensitivity studies for the ice flow of the Ross Ice Shelf, Antarctica, J. Geophys. Res., 110(F4), F04022, doi:10.1029/2004JF000170, 2005.

Humbert, A. and Braun, M.: Wilkins Ice Shelf - break-up along failure zones, J. Glaciol., 55(188), 943-944, 2008.

Humbert, A. and Pritchard, H.: Numerical simulations of the ice flow dynamics of the Brunt Ice Shelf - Stancomb Wills Ice Tongue System, FRISP report, 17, 85-97, 2006.

King, J. C.: Recent climate variability in the vicinity of the Antarctic Peninsula, Int. J. Climatol., 14, 357-369, 1994.

King J. C. and Harangozo, S. A.: Climate change in the western Antarctic Peninsula since 1945: observations and possible causes, Ann. Glaciol., 27, 571-575, 1998.

Liu, H., Jezek, K., Li, B., and Zhao, Z.: Radarsat Antarctic Mapping Project digital elevation model version 2. Boulder, CO: National Snow and Ice Data Center, Digital media, 2001.

Lucchita, B. K. and Rosanova, C. E.: Retreat of northern margins of GeorgeVI and Wilkins Ice Shelves, Antarctic Peninsula, Ann. Glaciol., 27, 41-46, 1998.

Lythe, M. B., Vaughan, D. G. and the BEDMAP Consortium: BEDMAP - bed topography of the Antarctic. 1:10000000 scale man. BAS (Misc) 9, Cambridge, British Antarctic Survey, UK, 2000.

MacAyeal, D. R., Scambos, T. A., Hulbe, C. L., and. Fahnestock, M. A: Catastrophic ice shelf break-up by an ice-shelf-fragmentcapsize mechanism, J. Glaciol., 29(164), 22-36, 2003.

Mantripp, D. R., Ridley, J. K., and Rapley, C. G.: Antarctic map from the Geosat Radar Altimeter Geodetic Mission, Earth Observ. Quart., 37-38, 6-10, 1992.

Meredith, M. P. and King, J. C.: Climate change in the ocean to the west of the Antarctic Peninsula during the second half of the 20th century, Geophys. Res. Lett., 32, L19604, doi:10.1029/2005GL024042, 2005.

Morris, E. M. and Mulvaney, R.: Recent variations in surface mass balance of the Antarctic Peninsula ice sheet, J. Glaciol., 50(169), 257-267, 2004.

Morris, E. M. and Vaughan, D. G.: Spatial and temporal variation of surface temperature on the Antarctic Peninsula and the limit of viability of ice shelves, Ant. Res. Ser., 79, 61-68, 2003.

Peel, D. A. and Clausen, H. B.: Oxygen isotope and total betaradioactivity measuremens on $10 \mathrm{~m}$ ice cores from the Antarctic Peninsula, J. Glaciol., 28(98), 43-55, 1982.

Pritchard, H. D. and Vaughan, D. G.: Widespread acceleration of tidewater glaciers on the Antarctic Peninsula, J. Geophys. Res., 112, F03S29, 1-10, doi:10.1029/2006JF000597, 2007.

Rau, F., Mauz, F., de Angelis, H., Jaña, R., Arigony Neto, J., Skvarca, P., Vogt, S., Saurer , H., and Gossmann, H.: Variations of glacier frontal positions on the northern Antarctic Peninsula, Ann. Glaciol., 39, 525-530, 2003.

Ridley, J.: Surface melting on Antarctic Peninsula ice shelves detected by passive microwave sensors, Geophys. Res. Lett., 
20(23), 2639-2642, 1993.

Rignot, E., Braaten, D., Gogineni, S. P., Krabill, W. B., and McConnell, J. R.: Rapid ice discharge from southeast Greenland glaciers, Geophys. Res. Lett., 31, L10401, doi:10.1029/2004GL019474, 2004.

Rignot, E., Casassa, G., Gogineni, S., Kanagaratnam, P., Krabill, W., Pritchard, H., Rivera, A., Thomas, R., Turner, J., and Vaughan, D.: Recent ice loss from the Fleming and other glaciers, Wordie Bay, West Antarctic Peninsula, Geophys. Res. Lett., 32, L07502, doi:10.1029/2004GL021947, 2005.

Rott, H., Skvarca, P., and Nagler, T.: Rapid collapse of northern Larsen Ice Shelf, Antarctica, Science, 271, 5250, 788-792, 1996.

Rott, H., Rack, W., Nagler, T., and Skvarca, P.: Climatically induced retreat and collapse of northern Larsen Ice Shelf, Antarctic Peninsula, Ann. Glaciol., 27, 86-92, 1998.

Rott, H., Rack, W., Skvarca, P., and Angelis, H. D.: Northern Larsen Ice Shelf, Antarctica: further retreat after collapse, Ann. Glaciol., 34, 277-282, 2002.

Scambos, T., Hulbe, C., Fahnestock, M., and Bohlander, J.: The link between climate warming and break-up of ice shelves in the Antarctic Peninsula, J. Glaciol., 46, 516-530, 2000.

Scambos, T., Hulbe, C., and Fahnestock, M.: Climate-induced ice shelf disintegration in the Antarctic Peninsula. In Antarctic Peninsula climate variability: historical and paleoenvironmental perspectives, Ant. Res. Ser., 79, 79-92, 2003.

Scambos, T. A., Bohlander, J. A., Shuman, C. A., and Skvarca, P.: Glacier acceleration and thinning after ice shelf collapse in the Larsen-B embayment, Antarctica, Geophys. Res. Lett., 31, 1-4, 2004.

Schulson, E. M.: The Structure and Mechanical Behavior of Ice, J. Mater., 51, 21-27, 1999.

Shabtaie, S. and Bentley, C. R.: Tabular Icebergs: Implications from geophysical studies of ice shelves, J. Glaciol., 28(100), 413-430, 1982.

Shepherd, A., Wingham, D., Payne, T., and Skvarca, P.: Larsen Ice Shelf Has Progressively Thinned, Science, 302(5646), 856-859, doi:10.1126/science.1089768, 2003.

Simmons, D. A.: Flow of the Brunt Ice Shelf, Antarctica, derived from Landsat images, 1974-1985, J. Glaciol., 32(111), 252-254, 1986.

Sievers, J. and Bennat, H.: Reference systems of maps and geographic information systems of Antarctica, Ant. Sci., 1, 351-362, 1989.

Skvarca, P.: Fast recession of the northern Larsen Ice Shelf monitored by space images, Ann. Glaciol., 17, 317-321, 1993.

Skvarca, P., Rack, W., Rott, H., Ibarzábal, T., and Donángelo, T.: Evidence of recent climatic warming on the eastern Antarctic Peninsula, Ann. Glaciol., 27, 628-632, 1999.

Smith, B. M. E.: Airborne radio echo sounding of glaciers in the Antarctic Peninsula, Br. Antarct. Surv. Sci. Rep., 72, 11 pp., 1972.

Swithinbank, C.: Satellite image atlas of glaciers of the world: Antarctica, US Geol. Sur. Pro. Pap., 1386-B, 1988.

Tedesco, M.: Updated 2008 surface snowmelt trends in Antarctica, Eos Trans., 89(13), 126, doi:10.1029/2008EO130002, 2008.
Thomas, E. R., Marshall, G. J., and McConnell, J. R.: A doubling in snow accumulation in the western Antarctic Peninsula since 1850, Geophys. Res. Lett., 35, L01706, doi:10.1029/2007GL032529, 2008.

Torinesi, O., Fily, M., and Genthon, C.: Interannual variability and trend of the Antarctic ice sheet summer melting period from 20 years of spaceborne microwave data, J. Climate, 16, 1047-1060, 2003.

Turner, J., Colwell, C. R., and Harangozo, S.: Variability of precipitation over the western Antarctic Peninsula from synoptic observations, J. Geophys. Res., 102(D12), 13999-14007, 1997.

Turner, J., Colwell, S. R., Marshall, G. J., and Lachlan-Cope, T. A.: Antarctic Climate Change During the last 50 Years, Int. J. Climatol., 25, 279-294, 2005.

Uenzelmann-Neben, G., Gohl, K., Larter, R. D., and Schlüter, P.: Differences in ice retreat across Pine Island Bay, West Antarctica, since the Last Glacial Maximum: Indications from multichannel seismic reflection data. U.S.Geological Survey and The National Acadamies; USGS OF-2007-1047, Short Research Paper 084, doi:10.3133/of2007-1047.srp084, 2007.

Van der Veen, C. J.: Fracture mechanics approach to penetration of bottom crevasses on glaciers, Cold Reg. Sci. Technol., 27, 213 223, 1998.

Vaughan, D. G., Mantrupp, D. R., Sievers, J., and Doake, C. S. M.: A synthesis of remote sensing data on Wilkins Ice Shelf, Antarctica, Ann. Glaciol., 17, 211-218, 1993.

Vaughan, D. G. and Doake, C. S. M.: Recent atmospheric warming and retreat of ice shelves on the Antarctic Peninsula, Nature, 379, 328-331, 1996.

Vaughan, D. G.: A new classification scheme for ice shelves based on mechanisms of mass gain and loss, Polar Rec., 34(188), 56$58,1998$.

Vaughan, D. G., Marshall, G. J., Connolley, W. M., King, J. C., and Mulvaney, R.: Devil in the Detail, Science, 293, 5536, 17771779, 2001.

Vaughan, D.: Recent trends in melting conditions on the Antarctic Peninsula and their implications for ice-sheet mass balance and sea level, Arctic, Ant. Alp. Res., 38(1), 147-152, 2006.

Vieli, A., Payne, A. J., Shepherd, A., and Du, Z.: Causes of precollapse changes of the Larsen B ice shelf: numerical modelling and assimilation of satellite observations, Earth Planrt Sci. Lett., 259, 297-306, 2007.

Ward, C. G.: Mapping ice front changes of Mueller Ice Shelf, Antarctic Peninsula, Antarct. Sci., 7(2), 197-198, 1995.

Weeks, W. F. and Ackley, S. F.: The growth, structure and properties of sea ice, CRREL Monographs, 82-1, 1982.

Zwally, H. J., Giovinetto, M. B., Li, J., Cornejo, H. G., Beckley, M. A., Brenner, A. C., Saba, J. L., and Yi, D.: Mass changes of the Greenland and Antarctic ice sheets and shelves and contributions to sea level rise: 1992-2002, J. Glaciol., 51, 509-527, 2005.

Zotikov, I. A., Zagorodnov, V. S., and Raykovskiy, Y. V.: Core drilling through the Ross Ice Shelf (Antarctica) confirmed basal freezing, Science, 207, 4438, 1463-1465, 1980. 